\title{
Physicochemical properties and physiological activities of Agastache rugosa extracts
}

\author{
Ji Wan Kim, Joo-Heon Hong* \\ Department of Food Science and Technology, Deagu Catholic University, Gyeongsan 38430, Korea
}

\section{배초향 추출물의 이화학적 품질 특성 및 생리활성}

\author{
김지완 · 홍주헌* \\ 대구가톨릭대학교 식품공학과
}

\begin{abstract}
Agastache rugosa is used as a medicinal herb and contains various polyphenol compounds. Here, we investigated the physicochemical properties; and the immunomodulatory and anti-obesity effects of Agastache rugosa extracts. Agastache rugosa was extracted with hot water (HE), 70\% ethanol (EE), and $70 \%$ methanol (ME). The yield of Agastache rugosa extracts varied depending on the extraction solvents, from 6.11 to $-8.86 \%$. The total sugar content was the highest in the HE - $(33.98 \mathrm{~g} / 100 \mathrm{~g})$. In contrast, the total polyphenol content was the highest in the ME $-(10.25 \mathrm{~g} / 100 \mathrm{~g})$, while the total protein content was similar in all extracts. The DPPH radical scavenging activity of the ME was $61.05 \%$, and the ABTS radical scavenging activity of the EE was $47.73 \%$ at $1,000 \mu \mathrm{g} / \mathrm{mL}$. Additionally, the FRAP activity and ORAC value of the EE at $1,000 \mu \mathrm{g} / \mathrm{mL}$ were $1.14 \mu \mathrm{M}$ and $121.03 \mu \mathrm{M} \mathrm{TE} / \mathrm{g}$, respectively. Importantly, all extracts decreased the production of nitric oxide in RAW 264.7 cells, and the cytokine content also decreased in a concentration-dependent manner. In addition, all extracts decreased lipid accumulation in adipocytes in vitro, compared with that in the untreated adipocytes. Therefore, Agastache rugosa extracts can potentially be used as functional materials with immunomodulatory and anti-obesity effects.
\end{abstract}

Key words : Agastache rugosa, physicochemical properties, antioxidants, immunomodulatory effect, anti-obesity activity

서 론

국민 소득수준 향상으로 인해 식생활의 서구화 등 생활 스 타일의 변화에 따라 비만 및 당뇨병과 같은 각종 성인병 발병 률이 증가하고 있다(Oh, 2016). 비만은 과다한 에너지 섭취 로 인해 체내 대사활동으로 다 사용되지 못한 에너지가 중성 지방으로 전환된 후, 지방조직에 축적되어 체지방이 과다된 상태를 의미한다(Chua와 Leibel, 1997). 지방조직은 다양한 아디포카인 및 사이토카인 내분비와 관련된 중요한 역할을
하며(Castoldi, 2016), 지방조직으로 인한 과도한 에너지의 축 적은 지방세포의 비대와 이상 증식뿐만 아니라, leukocytes, granulocytes 및 dendritic cells와 같은 다양한 면역세포의 과 도한 염증 인자 생성으로 인해 낮은 수준의 만성적인 염증이 나타난다(Kalupahana 등, 2012; Rose 등, 2015).

염증 반응은 염증성 매개물질을 분비하는 신체 보호 작용 중 하나지만, 염증 매개물질의 과다 분비 시 암을 유발하게 하고, 인슐린 저항성 증가로 인해 당뇨 등 다양한 질병들을 유발할 수 있다(Lee 등, 2011). 대식세포는 염증에 관여하는

*Corresponding author. E-mail : jhhong@cu.ac.kr, Phone : +82-53-850-3218, Fax : +82-53-850-3218

Received 26 November 2020; Revised 22 January 2021; Accepted 28 January 2021.

Copyright (c) The Korean Society of Food Preservation.

This is an Open Access article distributed under the terms of the Creative Commons Attribution Non-Commercial License (http://creativecommons.org/licenses/by-nc/4.0) which permits unrestricted non-commercial use, distribution, and reproduction in any medium, provided the original work is properly cited. 
주요 세포로, 다양한 자극이나 면역세포들이 분비하는 사이토 카인 등에 의해 활성화되어 염증성 사이토카인, nitric oxide (NO)와 $\mathrm{PGE}_{2}$ (prostaglandin $\mathrm{E}_{2}$ )를 생성함으로써 염증 반응을 유발하고, 면역세포의 이동을 활성화 하며(Kim 등, 2012), 이 러한 염증 반응이 항염증 반응에 의해 제한될 때 신체의 건강 및 항상성을 유지할 수 있다. 염증 반응과 관련된 다양한 사이 토카인에는 CRP 및 TNF(tumor necrosis factor)등이 있으며, 특히 TNF는 다른 세포를 활성화시켜 IL-1과 같은 다른 종류 의 사이토카인, 산화질소 및 활성산소종과 같은 매개체를 분 비하게 하여 염증 반응을 확대시켜 비만 및 대사증후군 등 만 성염증 반응과 관련 있는 것으로 보고되었으며(Park 과 Yoo, 2004), 이러한 사이토카인들의 생성은 다양한 대사성 질환 발 생과 밀접한 관련이 있는 것으로 알려져 있다(Park 등, 2020).

배초향은 꿀풀과에 속하는 다년생 초본으로 주로 아시아 지역에 서식하며, 우리나라에서는 예로부터 한방에서 소화 및 감기와 같은 질환에 사용되어 왔다(Cho 등, 2011; Lee 등, 1994). 배초향에는 rosmarinic acid와 같은 폴리페놀 화합물 이 함유되어 있으며, 그 중 플라보노이드계 화합물인 tilianin, acacetin 및 agastachin 등이 다량 함유되어 있어 항산화 효 과, 항암효과, 항염증, 항바이러스 효과 및 항균성 등의 기능 을 나타내는 것으로 알려져 있다(Chen과 Ho, 1997; Kim 등, 2015). 최근 배초향 추출물의 피부 항노화 활성 및 미백효과 와 관련된 연구들이 보고되어(Park 등, 2019; Yun 등, 2019) 배초향 추출물의 피부 기능성 효과에 대한 관심 또한 증가하 였다. 이처럼 배초향 추출물의 항산화 활성 및 피부 기능성 효과와 관련된 연구들은 많이 진행되었으나, 추출물의 면역 조절 효과 및 항비만 활성 관련 연구는 아직 미비한 실정이다. 따라서 본 연구에서는 추출 용매에 따른 배초향 추출물의 이화학적 품질 특성과 항산화 활성, RAW 264.7 cell을 이용 한 면역조절 효과 및 3T3-L1 cell을 이용한 항비만 활성을 조사하였으며, 이를 통해 기능성식품 소재로서의 활용 가능 성을 확인하고자 하였다.

\section{재료 및 방법}

\section{실험재료}

본 연구에 사용된 건조 배초향(Agastache rugosa, 국내산) 은 두손애약초(주)(Yeongcheon, Korea)에서 구입 후, 상온에 보관하였으며, 수분함량 $5 \%$ 미만으로 건조 후 분쇄하여 40 mesh 표준망체를 통과한 분말을 $-70^{\circ} \mathrm{C}$ 이하의 암소에 보관하 며 추출용 시료로 사용하였다.

\section{추출물 제조}

배초향 분말 $30 \mathrm{~g}$ 에 증류수, $70 \%$ 에탄올 및 $70 \%$ 메탄올
을 $300 \mathrm{~mL}$ 첨가하여 각각 $100^{\circ} \mathrm{C}$ 및 $80^{\circ} \mathrm{C}$ 에서 4 시간 동안 환류냉각추출기(CA-1112, Eyela Co., Tokyo, Japan)를 사용 하여 추출하였다. 추출 후 불순물 제거를 위해 여과지 (Whatman No.4, Whatman International Ltd., Maidstone, England)를 사용하였으며, 여과 후 감압농축기(N-1N, Eycla Co., Tokyo, Japan)로 농축하여 동결건조기(Free Zone 2.5, Labconco Co., Kansas city, MO, USA)로 건조 후 $-70^{\circ} \mathrm{C}$ 이 하의 암소에서 보관하며 분석용 시료로 사용하였다.

\section{수율, 총당 및 총단백질 함량 측정}

수율은 각 추출 용매별로 제조한 배초향 추출물을 동결건 조하여 건물 중량을 구한 후 시료 제조 시 사용한 원료건물량 대비 백분율(\%)로 나타내었다.

총당 함량은 phenol-sulfuric acid법(Dubois 등, 1956)을 응 용하여 측정하였다. 시료 $1 \mathrm{~mL}$ 에 $5 \%$ phenol $1 \mathrm{~mL}$ 를 첨가하 고 sulfuric acid $5 \mathrm{~mL}$ 를 혼합 후, 20 분간 실온에서 반응시킨 후 $470 \mathrm{~nm}$ 에서 분광광도계(Ultraspec 2100pro, Biochrom Ltd., Cambridge, UK)를 이용하여 측정하였다. 총당 함량은 표준물질 glucose(Sigma-Aldrich Co., St. Louis, MO, USA) 로 작성한 표준정량곡선으로 계산하였다.

총단백질 함량은 Bradford법(Bradford, 1976)을 응용하여 측정하였다. 시료 $0.2 \mathrm{~mL}$ 에 $5 \times$ 에서 $1 \times$ 로 희석한 Bradford reagent $0.8 \mathrm{~mL}$ 를 첨가하여 5 분 동안 상온 방치 후 multi microplate reader(Infinite 200 PRO, Asys Co., Tecan, Salzburg, Austria)를 이용하여 $595 \mathrm{~nm}$ 에서 흡광도를 측정하 였다. 총단백 함량은 표준물질 BSA(Bovine serum albumin, Sigma-Aldrich Co.)으로 작성한 표준정량곡선으로 계산하 였다.

\section{총폴리페놀 함량 측정}

총폴리페놀(phenol) 함량은 Folin-Denis법(Singleton과 Rossi, 1965)을 응용하여 측정하였다. 시료 $1 \mathrm{~mL}$ 에 2 배 희석한 2 $\mathrm{N}$ Folin-Ciocalteu phenol reagent $1 \mathrm{~mL}$ 를 혼합한 다음 $20 \%$ sodium carbonate $1 \mathrm{~mL}$ 를 첨가하여 30 분 동안 암소에서 반 응시킨 후 분광광도계(Ultrospec 2100pro, Biochrom Ltd.)를 이용하여 $725 \mathrm{~nm}$ 에서 흡광도를 측정하였다. 총폴리페놀 함 량은 표준물질 tannic acid(Sigma-Aldrich Co.)로 작성한 표 준정량곡선으로 계산하였다.

\section{DPPH radical 소거활성 측정}

DPPH radical 소거활성은 1,1-diphenyl-2-pycrylhydrazyl $(\mathrm{DPPH})$ 의 환원력을 이용하여 측정하였다(Blois, 1958). 즉, DPPH reagent는 DPPH(Sigma-Aldrich Co.) $12 \mathrm{mg}$ 을 99.9\% ethanol $100 \mathrm{~mL}$ 에 용해한 후 증류수 $100 \mathrm{~mL}$ 첨가하여 흡광 
도를 $517 \mathrm{~nm}$ 에서 약 1.50으로 조정하여 제조하였다. 시료 $0.5 \mathrm{~mL}$ 에 DPPH reagent $5 \mathrm{~mL}$ 를 혼합하여 실온에서 15 분간 반응시킨 후 분광광도계(Ultrospec 2100pro, Biochrom Ltd.) 를 이용하여 $517 \mathrm{~nm}$ 에서 흡광도를 측정하였다.

DPPH radical scavenging activity $(\%)=\left(1-\frac{S}{C}\right) \times 100$

$S$ : absorbance of sample at $517 \mathrm{~nm}$

$C$ : absorbance of control at $517 \mathrm{~nm}$

\section{ABTS radical 소거활성 측정}

2,2'-Azino-bis(3-ethylbenzothiazoline-6-sulfonic acid)(ABTS) radical 소거활성은 양이온(ABTS $\left.{ }^{+}\right)$에 대한 항산화물질의 소 거능을 이용하여 측정하였다( $\operatorname{Re}$ 등, 1999). ABTS reaction mixture는 $7.4 \mathrm{mM}$ ABTS(Sigma-Aldrich Co.)와 $2.6 \mathrm{mM}$ potassium persulfate를 최종 농도로 혼합하여 실온인 암소에 서 24시간 동안 방치하여 $\mathrm{ABTS}^{+}$을 형성시킨 후 $732 \mathrm{~nm}$ 에서 흡광도 값이 $0.70 \pm 0.03$ 이 되게 증류수를 사용하여 희석하였 다. 시료 $50 \mu \mathrm{L}$ 에 $\mathrm{ABTS}$ reaction mixture $950 \mu \mathrm{L}$ 를 첨가하 여 혼합 후 실온에서 10 분간 반응시킨 다음 multi microplate reader(Asys Co.)를 이용하여 $732 \mathrm{~nm}$ 에서 흡광도를 측정하 였다. ABTS radical 소거활성은 시료의 첨가 전과 후의 차이 를 아래와 같이 백분율로 나타내었다.

ABTS radical scavenging activity $(\%)=\left(1-\frac{S}{C}\right) \times 100$

$S$ : absorbance of sample at $732 \mathrm{~nm}$

$C$ : absorbance of control at $732 \mathrm{~nm}$

\section{FRAP 활성 측정}

FRAP(ferric reducing antioxidant power)는 Benzie와 Strain의 방법(Benzie과 Strain, 1996)에 따라 다음과 같이 측 정하였다. FRAP reagent는 $25 \mathrm{~mL}$ acetate buffer $(300 \mathrm{mM}$, $\mathrm{pH}$ 3.6)를 $40 \mathrm{mM} \mathrm{HCl}$ 에 용해한 $10 \mathrm{mM}$ 2,4,6-tris(2pyridyl)-s-triazine(TPTZ, Sigma-Aldrich Co.) $2.5 \mathrm{~mL}$ 와 20 $\mathrm{mM}$ ferric chloride $\left(\mathrm{FeCl}_{3} \cdot 6 \mathrm{H}_{2} \mathrm{O}\right) 2.5 \mathrm{~mL}$ 를 첨가하여 제조 하였으며, 실험 직전 $37^{\circ} \mathrm{C}$ 에서 10 분 이상 반응시켜 사용하였 다. 시료 $25 \mu \mathrm{L}$ 에 제조된 FRAP reagent $175 \mu \mathrm{L}$ 를 넣고 $37^{\circ} \mathrm{C}$ 암소에서 30 분간 반응시킨 후, multi microplate reader(Asys $\mathrm{Co}$.)를 이용하여 $590 \mathrm{~nm}$ 에서 흡광도를 측정하였다. FRAP는 $\mathrm{FeSO}_{4} \cdot 7 \mathrm{H}_{2} \mathrm{O}$ (Sigma-Aldrich Co.)을 정량하여 작성한 표준 곡선으로부터 계산하였다.

\section{ORAC value 측정}

ORAC(oxygen radical absorbance capacity)은 $\mathrm{Ou}$ 등
(2001)의 방법에 준하여 측정하였다. 시료 제조 시 중성 phosphate buffer(61.6:38.9, v/v, $\left.75 \mathrm{mM} \mathrm{NaH} \mathrm{PO}_{4}\right)$ 를 사용하 여 동결건조 분말 및 trolox를 농도별 희석 후 사용하였다. 검량곡선 작성을 위해 trolox(water soluble analogue of vitamin E, 6-hydroxy-2,5,7,8-tetramethylchromane-2-carboxylic acid, Sigma-Aldrich Co.) $10 \mu \mathrm{L}$ 를 $50 \mathrm{~mL}$ phosphate buffer 를 사용하여 제조하였으며, 측정기기는 fluorescent micro plate reader(Infinite M200 PRO, Tccan Co., Salzburg, Austria)를 사용하여 $485 \mathrm{~nm}$ 에서 전자가 여기되고, $538 \mathrm{~nm}$ 에서 방출되게 조절 후 측정하였다.

\section{세포주 배양}

마우스 대식세포(RAW 264.7) 및 마우스 지방전구세포인 3T3-L1 세포는 한국세포주은행(KTCC, Seoul, Korea)에서 분양받아 사용하였으며, DMEM 배지(Welgene Co., Daegu, Korea)에 10\% fetal bovine serum(Gibco BRL Co., Crewe, Cheshire, UK) 및 2\% penicillin-streptomycin(Gibco BRL $\mathrm{Co}$.)을 첨가하여 사용하였으며, $37^{\circ} \mathrm{C}, 5 \% \mathrm{CO}_{2}$ 로 조절된 incubator(MCO-18 AIC, Sanyo Co., Osaka, Japan)에서 배양 하였다.

\section{세포독성 측정}

배초향 추출물의 RAW 264.7 세포 및 3T3-L1 세포의 세 포독성은 3-(4,5-dimethylthiazol-2-yl)-2,5-diphenyltetrazolium bromide(MTT, Sigma-Aldrich Co.) 시약의 환원 정도를 측정 하는 MTT assay 방법(Van 등, 2011)을 사용하여 측정하였 다. 배양된 세포주를 $1 \times 10^{4}$ cell $/ \mathrm{mL}$ 로 96-well plate에 첨가하 여 24시간 배양하고 $50-1,000 \mu \mathrm{g} / \mathrm{mL}$ 농도로 제조한 시료를 처리한 후 12 시간 동안 배양하였다. 배양 후 PBS 완충용액에 녹인 MTT 용액 $(5 \mathrm{mg} / \mathrm{mL})$ 을 각 well에 $10 \mu \mathrm{L}$ 씩 첨가하고, 다시 4시간 동안 배양하여 MTT가 환원되도록 하였다. 배양 종료 후 생성된 formazan 결정이 흐트러지지 않게 상등액을 완전히 제거한 다음 각각의 well에 $100 \mu \mathrm{L}$ 씩 dimethyl sulfoxide(DMSO, Junsei Chemical Co., Tokyo, Japan)를 첨 가하고, 실온에서 10 분간 반응시켜 formazan 결정을 완전히 용해한 다음 multi microplate reader(Asys Co.)를 이용하여 $540 \mathrm{~nm}$ 에서 흡광도를 측정하였다. 세포 생존율은 시료를 처 리하지 않은 세포를 대조군으로 하여 상대적인 백분율로 나 타내었다.

\section{Nitric oxide 생성량 측정}

RAW 264.7 세포를 이용한 nitric oxide 생성량은 Rao (1997)의 방법을 참고하여 측정하였다. 배양된 세포주를 96 well plate에 $5 \times 10^{4}$ cell/well의 농도로 $100 \mu \mathrm{L}$ 씩 첨가하여 24 
시간 배양 후 배지교환 및 $10 \mu \mathrm{L}$ 의 lipopolysaccharide(LPS, $0.15 \mu \mathrm{g} / \mathrm{mL}$, Sigma-Aldrich Co.)와 동량의 시료를 농도별로 처리하여 24시간 동안 배양하였다. 배양된 상등액 $50 \mu \mathrm{L}$ 와 Griess시약(Sigma-Aldrich Co.) $50 \mu \mathrm{L}$ 를 혼합 후 $37^{\circ} \mathrm{C}, 5 \%$ $\mathrm{CO}_{2}$ 로 조절된 incubator(MCO-18 AIC, Sanyo Co.)에서 10 분간 반응시켰다. 반응 후 $540 \mathrm{~nm}$ 로 조정한 multi microplate reader(Asys Co.)를 사용하여 흡광도를 측정하였다. $\mathrm{NaNO}_{2}$ 로 작성한 표준정량곡선으로 nitric oxide 함량을 계산하였다.

\section{Cytokine 함량 측정}

RAW 264.7 세포를 이용한 cytokines 함량은 Dong 등 (1994)의 방법을 참고하여 측정하였다. 24 well plate에 $5 \times 10^{4}$ cell/well의 농도로 $1 \mathrm{~mL}$ 씩 첨가하여 24시간 배양 후 배지교환 및 $10 \mu \mathrm{L}$ 의 lipopolysaccharide(LPS, $0.1 \mu \mathrm{g} / \mathrm{mL}$, Sigma-Aldrich Co.) 동량의 시료를 농도별로 처리하여 24시 간 동안 배양하였다. 배양된 상등액을 이용하여 ELISA kit (eBioscience, Inc., 10255 Science Center Dr., San Diego, USA)으로 TNF- $\alpha$ 및 IL-6의 양을 분석하여 multi microplate reader(Asys Co.)를 이용하여 450nm에서 흡광도를 측정하였 다. Cytokines 함량은 TNF- $\alpha$ 및 IL-6으로 작성한 표준정량곡 선으로 계산하였다.

\section{T3-L1 지방전구세포의 분화 유도}

3T3-L1 지방전구세포의 분화유도는 Yeh 등(1995)의 방법 을 참고하였다. 24-well plate에 3T3-L1 세포를 $2.5 \times 10^{4}$ cell/well의 농도로 $1,000 \mu \mathrm{L}$ 씩 첨가하였으며, $100 \%$ confluent 상태가 되도록 배양하였다. 48 시간 더 배양 후 DMEM 배지 에 $\mathrm{MDI}(1 \mu \mathrm{M}$ dexamethasone, $0.5 \mathrm{mM}$ IBMX, $1 \mu \mathrm{g} / \mathrm{mL}$ insulin)를 첨가하여 배지교환 및 시료 처리를 하였으며, 48시 간 동안 지방세포 분화를 유도하였다. 48시간 간격으로 $\mathrm{DMEM}$ 배지에 $10 \% \mathrm{FBS}$ 와 $10 \mu \mathrm{g} / \mathrm{mL}$ insulin을 첨가하여 배 지 교환 및 $100 \mu \mathrm{L}$ 의 시료를 총 3회 처리하였으며, 마지막 시료 처리 후 48 시간 배양하여 완전 분화된 지방세포를 확인 하였다.

\section{Oil-Red 0 staining 및 정량분석}

Oil-Red O staining 및 정량분석은 Kang 등(2013)의 방법 을 참고하여 측정하였다. 지방세포 분화 완료 후 배지 제거 및 PBS(phosphate buffered saline $\mathrm{pH}$ 7.4)로 세척하였으며, $200 \mu \mathrm{L}$ 의 $10 \%$ formaldehyde 용액을 첨가하여 자연건조 후 $400 \mu \mathrm{L}$ 의 Oil-Red O solution(Sigma-Aldrich Co.)을 각 well 에 처리 후 암소에서 1 시간 염색하였다. 염색 완료된 지방을 세포 용해를 위해 $100 \%$ isopropanol $1 \mathrm{~mL}$ 를 첨가하였으며, $510 \mathrm{~nm}$ 에서 multi microplate reader(Asys Co.)를 이용하여 흡광도를 측정하였다.

\section{Free glycerol 함량 측정}

Free glycerol 함량 측정은 Lee 등(2014)의 방법을 참고하 여 측정하였다. 지방세포 분화 완료 후, 세포 배양액 $50 \mu \mathrm{L}$ 와 동량의 free glycerol reagent(Sigma-Aldrich Co.)를 첨가하여 $37^{\circ} \mathrm{C}, 5 \% \mathrm{CO}_{2}$ 로 조정된 incubator(MCO-18 AIC, Sanyo Co.)에서 30 분간 방치 후 $540 \mathrm{~nm}$ 에서 multi microplate reader (Asys Co.)를 이용하여 흡광도를 측정하였다. Free glycerol 함량은 Glycerol standard solution(Sigma-Aldrich Co.)으로 작성한 표준정량곡선으로 계산하였다.

\section{통계처리}

실험결과는 평균 \pm 표준편차로 나타내었고 $\operatorname{SPSS}(19.0, \mathrm{SPSS}$ Inc., Chicago, NY, USA)를 이용한 분산분석(ANOVA)을 실 시하였으며, 각 측정 평균값의 유의성 $(\mathrm{p}<0.05)$ 은 Duncan's multiple range test를 실시하여 검정하였다.

\section{결과 및 고찰}

\section{수율, 총당 및 총단백 함량}

추출 용매에 따른 배초향 추출물의 수율, 총당 및 총단백 함량은 Table 1과 같다. 열수, $70 \%$ 에탄올 및 $70 \%$ 메탄올 추출물의 수율은 각각 $8.86 \%, 6.11 \%$ 및 $6.93 \%$ 로 열수 추출 물에서 가장 높은 수율을 나타냈다. 천연물 내 생리활성 물질

Table 1. The yield, total sugar and total protein contents of Agastache rugosa extracts

\begin{tabular}{cccc}
\hline Sample ${ }^{1)}$ & $\begin{array}{c}\text { Yield } \\
(\text { dry basis, \%) }\end{array}$ & $\begin{array}{c}\text { Total sugar content } \\
(\text { glucose, g/100 g) }\end{array}$ & $\begin{array}{c}\text { Total protein content } \\
\left(\mathrm{BSA}^{2)}, \mathrm{g} / 100 \mathrm{~g}\right)\end{array}$ \\
\hline HE & 8.86 & $33.98 \pm 4.38^{\mathrm{a} 3)}$ & $9.33 \pm 0.06^{\mathrm{c}}$ \\
EE & 6.11 & $21.25 \pm 1.95^{\mathrm{b}}$ & $9.78 \pm 0.16^{\mathrm{b}}$ \\
ME & 6.93 & $25.32 \pm 3.34^{\mathrm{b}}$ & $10.25 \pm 0.00^{\mathrm{a}}$ \\
\hline
\end{tabular}

\footnotetext{
${ }^{1)} \mathrm{HE}$, hot-water extracts of Agastache rugosa; EE, 70\% ethanol extracts of Agastache rugosa; ME, 70\% methanol extracts of Agastache rugosa. ${ }^{2} \mathrm{BSA}$, bovine serum albumin.

${ }^{3)}$ Means \pm SD $(n=3)$ within each column $\left({ }^{a-c}\right)$ followed by the same letter represents no significant difference $(\mathrm{p}<0.05)$.
} 
들은 추출 용매의 종류에 따라 추출되는 성분들이 달라지며 (Cha 등, 2009), 추출 용매의 극성이 증가함에 따라 가용성 고형분의 용출량이 높아져(Dong 등, 2004), 열수 추출물의 수율이 가장 높게 나타난 것으로 판단된다.

총당 함량 측정 결과, 열수 추출물에서 $33.98 \mathrm{~g} / 100 \mathrm{~g}$ 으로 가장 높은 함량을 보였는데, 이는 용매인 물의 극성에 영향을 받은 것으로 사료된다. Park 등(2012)은 배초향 추출물의 총 당 함량 측정 결과, $5.37 \mathrm{~g} / 100 \mathrm{~g}$ 으로 나타났다고 보고하였는 데, 이는 재배환경에 따라 식물체 내의 수용성 탄수화물의 함 량이 달라진 것으로 판단된다(Anderson, 1986).

총단백 함량의 경우, $9.33-10.25 \mathrm{~g} / 100 \mathrm{~g}$ 으로 추출 용매별 로 유의적인 차이가 나타나지 않았으며, Park 등(2012)은 배 초향 추출물의 총단백 함량 측정 결과, $11.10 \mathrm{~g} / 100 \mathrm{~g}$ 으로 보 고하여 본 연구 결과와 유사한 함량을 나타내었다.

\section{총폴리페놀 및 ORAC value}

추출 용매에 따른 배초향 추출물의 총폴리페놀 함량 및 ORAC value 측정 결과를 Table 2에 나타내었다. 폴리페놀 화합물은 식물의 2 차 대사산물로서 수산기인 $\mathrm{OH}^{\top}$ 기를 가지 고 있어 체내에서 항산화제로서 작용하여 각종 질환 예방, 염 증 및 노화 예방과 같은 다양한 생리활성을 나타내는 물질로 그 함량이 증가할수록 생리활성 기능이 증가한다고 알려져 있다(Blois, 1958; Choi와 Chung, 2019). 총폴리페놀 함량 측 정 결과, $70 \%$ 메탄올 및 $70 \%$ 에탄올 추출물에서 각각 16.02 $\mathrm{g} / 100 \mathrm{~g}$ 및 $14.07 \mathrm{~g} / 100 \mathrm{~g}$ 으로 높은 함량을 나타냈으며, Ji 등 (2020)은 배초향 에탄올 추출물의 총폴리페놀 함량 측정 결 과, $34.51 \mathrm{mg}$ gallic acid equivalent $(\mathrm{GAE}) / \mathrm{g}$ 으로 보고하였다.

ORAC value는 수소 전자의 전달에 의한 환원력을 측정하 는 방법으로서 식품 내 수용성 및 지용성 성분 모두와 반응하 기 때문에 응용범위가 넓어 생물자원의 항산화 측정에 많이 이용되고 있다. 수용성 비타민 $\mathrm{E}$ 의 일종인 trolox를 표준물질 로 사용하였으며, peroxyl radical의 생성과 소멸에 대한 fluorescence의 감소율을 통해 항산화 활성을 측정하는 방법

Table 2. Total polyphenol and ORAC value of Agastache rugosa extracts

\begin{tabular}{ccc}
\hline Sample $^{1)}$ & $\begin{array}{c}\text { Total polyphenol } \\
(\text { tannic acid, g/100 g) }\end{array}$ & $\begin{array}{c}\text { ORAC value } \\
\text { (trolox, } \mu \text { M TE/g FW) }\end{array}$ \\
\hline HE & $10.10 \pm 0.11^{\mathrm{c} 2)}$ & $114.29 \pm 1.69^{\mathrm{b}}$ \\
$\mathrm{EE}$ & $14.07 \pm 0.57^{\mathrm{b}}$ & $121.03 \pm 0.60^{\mathrm{a}}$ \\
$\mathrm{ME}$ & $16.02 \pm 0.70^{\mathrm{a}}$ & $115.31 \pm 0.70^{\mathrm{b}}$ \\
\hline
\end{tabular}

${ }^{1)} \mathrm{HE}$, hot water extracts of Agastache rugosa; EE, 70\% ethanol extracts of Agastache rugosa; ME, 70\% methanol extracts of Agastache rugosa. ${ }^{2)}$ Means \pm SD $(n=3)$ within each column $\left({ }^{\mathrm{a}-\mathrm{c}}\right)$ followed by the same letter represents no significant difference $(\mathrm{p}<0.05)$.
으로 측정 감도가 예민하여 정확도를 높일 수 있는 방법이다 (Prior 등, 2005). 시료의 항산화 물질이 AAPH(2,2'-azobis(2methylpropionamidine)dihychloride)가 생성한 peroxyl radical 을 제거함으로써 fluorescence를 유지하며 시료의 항산화 활 성이 고갈될 때까지 측정되어 peroxyl radical에 대한 산화 방 지능을 측정한다. ORAC는 일정 시간이 지남에 따라 자유라 디칼에 의해 손상되어 발색되는 형광 값을 측정하여 결과를 확인하는 방법으로, 항산화 물질은 형광물질에 대한 자유라 디칼로부터의 손상을 방지하고, 안정적인 형광 시그널로 관 찰된다. 자유라디칼 생성을 위해 $\mathrm{AAPH}$ 를 사용하여 항산화 물질의 소거능력인 활성산소 흡수능력을 측정한다. 추출 용 매에 따른 배초향 추출물의 $\mathrm{ORAC}$ 측정 결과, $70 \%$ 에탄올 추출물에서 $121.03 \mu \mathrm{M} \mathrm{TE} / \mathrm{g}$ 으로 가장 높은 활성을 나타내었 는데, You 등(2018)은 약재로 사용되는 상백피 추출물의 ORAC value 측정 결과, $70 \%$ 에탄올 추출물에서 가장 높은 함량을 나타냈다고 보고하여 본 연구 결과와 유사한 경향이 었다. 에탄올은 소수성 및 친수성을 모두 가진 효과적인 용매 로서 물과의 혼합 정도에 따라 용매 성질인 극성과 밀도가 변하며, 삼투압에도 영향을 주어 용출되는 주요 성분에도 변 화가 나타난다고 보고하였는데(Kim과 Kim, 2019), 이런 까 닭에 $70 \%$ 에탄올 추출물의 $\mathrm{ORAC}$ 값이 가장 높게 나타난 것으로 사료된다.

\section{항산화 활성}

추출 용매에 따른 배초향 추출물의 DPPH radical 소거활 성, ABTS radical 소거활성 및 FRAP 활성을 Fig. 1에 나타내 었다. 모든 추출물에서 농도 의존적으로 활성이 증가하는 경 향이 나타났다. 활성산소는 체내에서 강한 산화력이 있어 세 포막 분해, 단백질 손상, DNA 합성 억제, 지방 산화와 같은 생리적인 장애를 유발하는 물질로 알려져 있으며(Lee 등, 2005), 항산화 물질은 활성산소에 의한 산화를 억제하는 물 질로서 질병 예방 및 노화 억제와 같은 다양한 생리활성을 가진다고 보고되었다(Yoon 등, 2003). 또한 DPPH 및 ABTS radical 소거활성은 각각 음이온 및 양이온 라디칼을 생성하여 식품의 항산화 활성 측정에 사용되며(Kwak과 Choi, 2015), FRAP 활성은 환원제인 antioxidant에 의해 $\mathrm{Fe}^{3+}-\mathrm{TPTZ}$ 복합 체가 파란색의 $\mathrm{Fe}^{2+}-\mathrm{TPTZ}$ 복합체로 될 때의 흡광도를 측정 하여 환원력을 분석하는 방법이다. DPPH 및 ABTS radical 소거활성은 각각 $70 \%$ 메탄올 및 $70 \%$ 에탄올 추출물 $(1,000$ $\mu \mathrm{g} / \mathrm{mL}$ )에서 $61.05 \%$ 및 $47.73 \%$ 로 나타났으며, FRAP 활성은 $70 \%$ 에탄올 추출물 $(1,000 \mu \mathrm{g} / \mathrm{mL})$ 에서 1.14 로 열수 추출물에 비해 높은 활성을 나타내었다. 추출 용매에 따른 배초향 추출 물의 항산화 활성 측정 결과, 열수 추출물에 비해 $70 \%$ 에탄올 및 $70 \%$ 메탄올 추출물에서 높은 항산화 활성을 나타내었는데, 
(A)

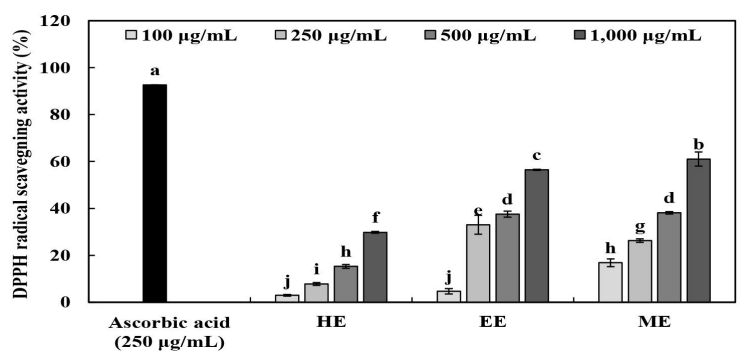

(B)

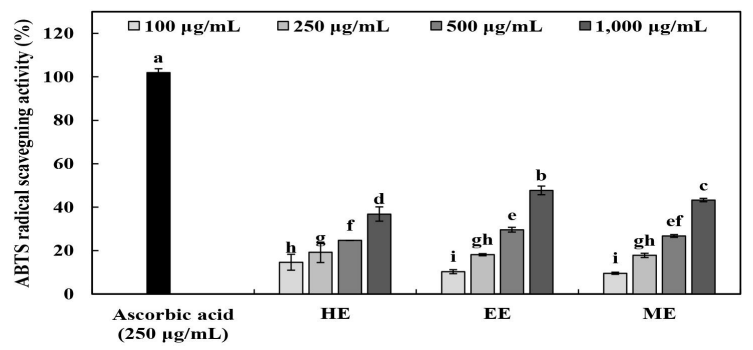

(C)

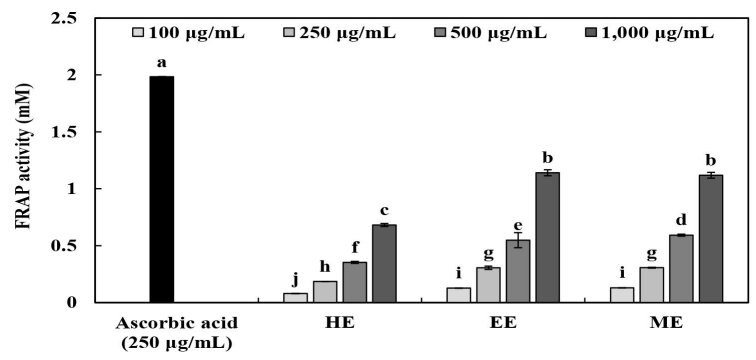

Fig. 1. DPPH radical scavenging activity (A), ABTS radical scavenging activity (B) and FRAP activity (C) of Agastache rugosa extracts.

HE, hot-water extract of Agastache rugosa; EE, 70\% ethanol extracts of Agastache rugosa; ME, 70\% methanol extracts of Agastache rugosa. Means \pm SD $(n=3)$ in each column $(\mathrm{a}-\mathrm{j})$ followed by the same letter represents no significant difference $(\mathrm{p}<0.05)$.

$\operatorname{Kim}$ 등(2017)은 매화꽃봉오리의 추출 용매별 항산화 효과 측 정 결과, 열수 추출물에 비해 에탄올 및 메탄올 추출물의 항산 화 효과가 높게 측정되어 본 연구와 유사한 경향이었다. 이는 추출 용매의 극성에 따라 추출된 생리활성 물질 및 폴리페놀 화합물의 용해도 차이에 의한 것으로 폴리페놀 함량과 밀접한 관련이 있는 것으로 사료된다(Ham 등, 2016; Kim 등, 2017).

\section{Nitric oxide 생성량}

염증 반응은 생체 조직의 방어 반응의 하나로 각종 cytokines과 protein 및 free radical 등 다양한 면역계 세포와 매개 물질들이 관여하고 있으며, 만성화가 진행되면 염증인 자의 과량 생산으로 인해 지속적인 염증반응을 유발하여 인 체의 각종 질환을 야기 및 악화시키는 원인이 되며(Kim 등, 2010; Yoon등, 2011), 최근 인슐린 저항성, 당뇨병, 고혈압 및 대사증후군 관련 질환의 원인으로 확대되고 있다(Park과
Yoo, 2004). 일반적으로 nitric oxide(NO)는 과발현 시 염증 반응 및 염증 매개체의 생합성을 촉진하여 염증을 심화시키 는 것으로 알려져 있으며(Yoon 등, 2011), 이러한 NO 생성 의 억제는 염증 반응의 만성화 및 과발현을 억제할 수 있는 것으로 알려져 있다.

추출 용매에 따른 배초향 추출물의 RAW 264.7 세포에 대 한 세포독성 및 $\mathrm{NO}$ 생성량을 Fig. 2에 나타내었다. RAW 264.7 세포에 대한 배초향 추출물의 세포독성 측정 결과, $100-1,000 \mu \mathrm{g} / \mathrm{mL}$ 농도에서 $95 \%$ 이상의 생존율을 나타내어 세포독성이 없음을 확인하였다. 대식세포에 자극을 주어 $\mathrm{NO}$ 생성을 유도하기 위해 LPS를 $1.5 \mathrm{mM}$ 농도로 처리하였으며, 모 든 시료에서 농도 의존적으로 $\mathrm{NO}$ 생성량이 감소함을 확인하 였다. $70 \%$ 에탄올 및 $70 \%$ 메탄올 추출물 $(1,000 \mu \mathrm{g} / \mathrm{mL})$ 에서 $7.55 \mu \mathrm{M}$ 및 $9.10 \mu \mathrm{M}$ 로 열수 추출물에 비해 $(11.43 \mu \mathrm{M})$ 우수한 $\mathrm{NO}$ 생성 억제능을 나타냈으며, 특히 $70 \%$ 에탄올 추출물의 경 우 LPS 첨가 대조군 $(32.54 \mu \mathrm{M})$ 대비 약 $23 \%$ 정도 감소하였 다. Yoon 등(2011)은 황금 추출물의 NO 생성량 측정 결과, $25-200 \mu \mathrm{g} / \mathrm{mL}$ 농도에서 $\operatorname{LPS}(1 \mu \mathrm{g} / \mathrm{mL})$ 처리군과 비교하여 유 의하게 감소하였으며, Song과 Lee(2017)는 망초 에탄올 추출 물이 농도 의존적으로 NO 생성을 억제했다고 보고하였다.

(A)

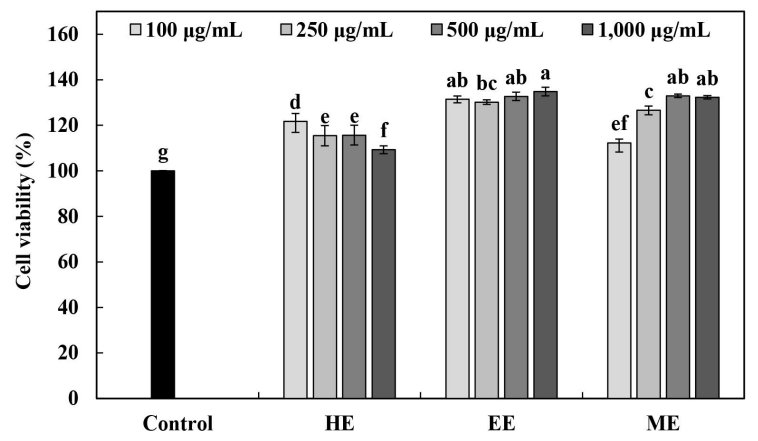

(B)

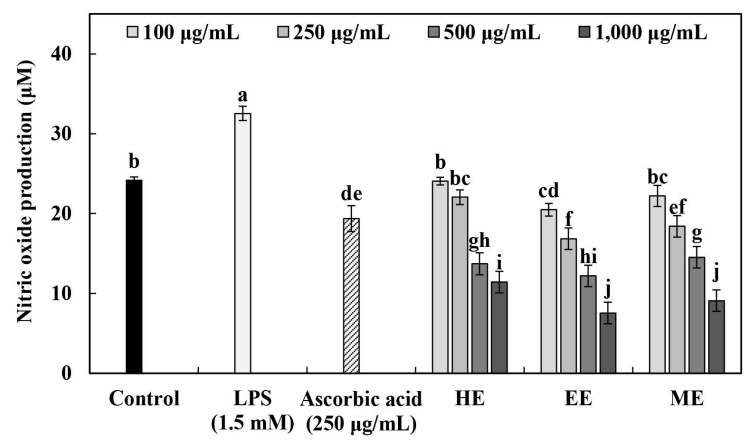

Fig. 2. MTT assay (A) and Nitric oxide production (B) in RAW 264.7 cell line treated with Agastache rugosa extracts.

HE, hot-water extract of Agastache rugosa; EE, 70\% ethanol extracts of Agastache rugosa; ME, 70\% methanol extracts of Agastache rugosa. Means \pm SD $(n=3)$ in each column $\left({ }^{a-j}\right)$ followed by the same letter represents no significant difference $(\mathrm{p}<0.05)$. 


\section{Cytokine 생성억제 효과}

TNF- $\alpha$ (tumornecrosis factor- $\alpha$ ) 및 IL(interleukin)- 6 는 염 증 유발인자로서 대식세포의 염증성 매개물질에 의해 생성되 며(Storck M 등, 1994), 과도하게 분비 시 만성적인 염증 반 응을 유발하여 인슐린 저항성을 증가시켜 동맥경화를 악화시 키는 등 다양한 질환 발병 기전에 관여한다고 보고되고 있다 (Cheon 등, 2009). TNF- $\alpha$ 는 림프조직의 발달을 조절하고, 혈 관 내피세포와 대식세포의 활성화를 유도하여 염증 반응을 촉진하며, IL-6는 골 흡수 촉진 등 다양한 생물학적 활성을 가지고 있어 염증 질환 발생에 따라 생성이 증가된다(Lee 등, 2005). 지방세포에서는 사이토카인으로 간에서 CRP의 생산 을 자극하는 전염증성 IL-6의 유전자 발현이 증가되어 전신 순환으로의 분비도 증가하며, 또한 과체중 및 비만인 사람의 경우 TNF- $\alpha$ 의 혈중농도가 유의하게 증가한다고 보고되었다 (Park과 Yoo, 2004).

$\mathrm{NO}$ 생성 억제능이 우수하게 나타난 배초향 $70 \%$ 에탄올 추출물을 50-250 $\mu \mathrm{g} / \mathrm{mL}$ 농도로 RAW 264.7 세포에 처리하 여 cytokines 함량을 측정하였다(Fig. 3). TNF- $\alpha$ 및 IL-6 함량 측정 결과, 모두 농도 의존적으로 함량이 감소하는 경향을 나 타내었다. TNF- $\alpha$ 함량 측정 결과, $54.06-70.57 \mathrm{pg} / \mathrm{mL}$ 로 LPS

(A)

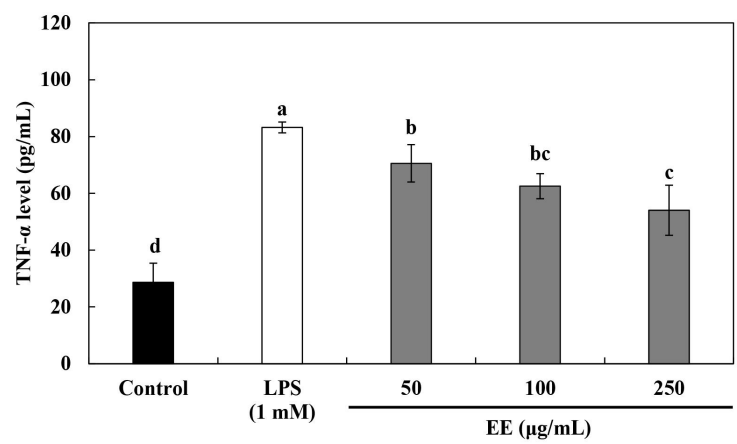

(B)

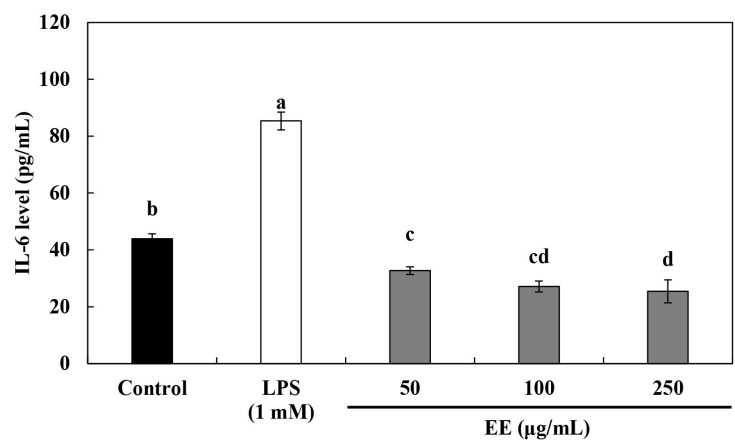

Fig. 3. TNF- $\alpha$ (A) and IL-6 production (B) in LPS (lipopolysaccharide) induced RAW 264.7 cell line treated with ethanol extract from Agastache rugosa extracts.

EE, $70 \%$ ethanol extracts of Agastache rugosa.

Means \pm SD $(n=3)$ in each column $\left(^{a-d}\right)$ followed by the same letter represents no significant difference $(\mathrm{p}<0.05)$.
$1 \mathrm{mM}$ 처리군 $(83.22 \mathrm{pg} / \mathrm{mL})$ 대비 함량이 감소하였으며, $\mathrm{Lim}$ 과 Lee(2020)는 향부추 $80 \%$ 에탄올 추출물의 TNF- $\alpha$ 함량 측정 결과, 농도 의존적으로 분비가 억제됐다고 보고하여 본 연구와 유사한 경향을 나타내었다. IL-6 함량 측정 결과, 25.41-32.68 pg/mL로 LPS $1 \mathrm{mM}$ 처리군 $(85.35 \mathrm{pg} / \mathrm{mL})$ 대비 낮은 함량을 나타내었다. Lee 등(2017)은 삼채 추출물의 IL-6 함량 측정 결과, LPS 처리군 대비 낮은 함량을 나타냈 으며, 농도 의존적으로 생성이 억제되었다고 보고하여 본 연 구와 유사하였는데, 이러한 연구 결과들을 통해 배초향 추출 물의 NO 생성 억제능뿐만 아니라, 사이토카인의 분비 또한 억제하여 면역조절물질로서의 활용가치가 높을 것으로 기대 된다. Yun 등(2019)은 5주령의 무모쥐(SKH-1)에 12주 동안 매일 1회 식염수 투여군, 배초향 추출물 $100 \mathrm{mg} / \mathrm{kg} / \mathrm{day}$ 투여 군, 배초향 추출물 $250 \mathrm{mg} / \mathrm{kg} /$ day 투여군의 IL-6, IL-1 1 및 $\mathrm{TNF}-\alpha$ 등의 염증성 사이토카인 함량 측정 결과, 배초향 추출 물이 12 주 후 염증성 사이토카인 유전자 발현량이 감소하였 다고 보고하였다.

\section{T3-L1 cell을 통한 지방세포 분화 억제효과 및 free glycerol 함량}

지방세포는 세포의 증식 및 분화로 인해 과발현되며 $(\mathrm{Ji}$ 등, 2012), TNF- $\alpha$ 및 IL-6 등의 염증성 사이토카인의 분비 증가 로 인해 비만에 의한 염증 반응은 대사성 질환의 주요 원인으 로 작용하는 것으로 확인되었다(Park 등, 2014). 추출 용매에 따른 배초향 추출물의 지방세포 분화억제 효과, Oil-Red O staining 및 free glycerol 함량 측정 결과는 Fig. 4 및 Fig. 5 와 같다. 추출 용매에 따른 배초향 추출물을 $100-1,000 \mu \mathrm{g} / \mathrm{mL}$ 농도로 MTT assay를 진행한 결과, $1,000 \mu \mathrm{g} / \mathrm{mL}$ 농도에서 세 포 독성을 나타내어 $50-500 \mu \mathrm{g} / \mathrm{mL}$ 농도로 처리하였으며, 모 든 시료 처리구간에서 세포독성이 나타나지 않음을 확인 후, Oil-Red O staining을 진행하여 지방전구세포의 분화억제 효 과를 측정하였다. 지방세포 분화유도 억제능 측정 결과, 배초 향 추출물을 처리하지 않고 분화만 유도한 군에서 세포 내 lipid droplet의 생성이 현저히 증가하는 것을 확인하였으며, 시료 처리구간별 6.88-29.48\%로 측정되었고, $70 \%$ 메탄올 추 출물 $500 \mu \mathrm{g} / \mathrm{mL}$ 농도(29.48\%)에서 가장 높은 억제능을 나타 낸 것을 확인하였다. 모든 배초향 추출물 처리구간에서 농도 의존적으로 지방세포 분화가 억제되는 것을 확인하였는데, $\operatorname{Kim}$ 등(2014)은 꿀풀과에 속하는 하고초 추출물의 지방세포 분화 억제능 측정 결과, 농도 의존적으로 생성이 저해되었다 고 보고하였으며, Kim 등(2017)은 약초로도 사용되어온 꿀 풀과의 배암차즈기 에탄올 추출물의 지방세포 분화 억제효과 측정 결과, $300 \mu \mathrm{g} / \mathrm{mL}$ 농도에서 $35 \%$ 의 억제능을 나타냈다 고 보고하였다. 
(A)

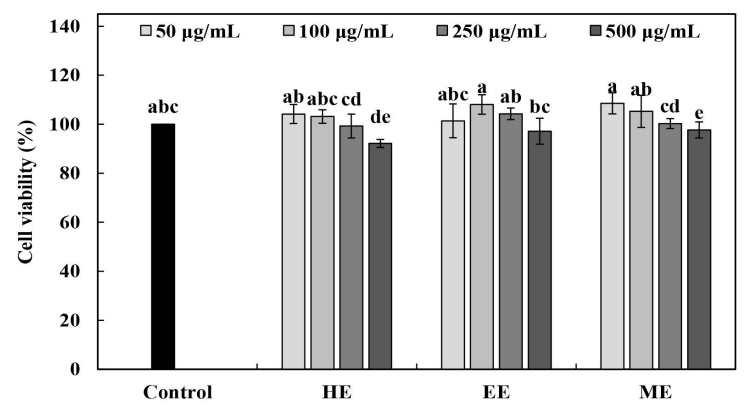

(B)

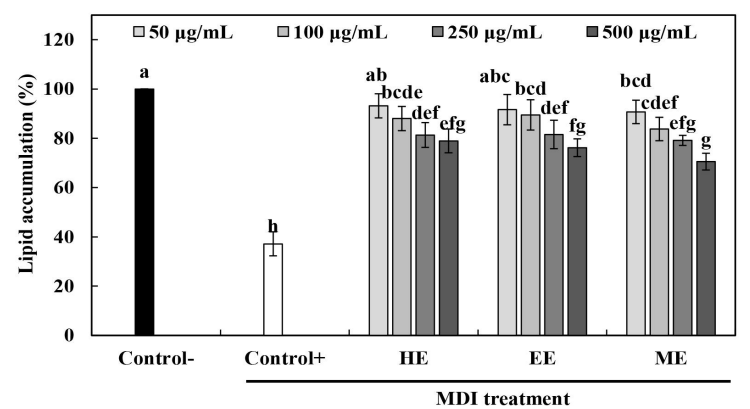

Fig. 4. MTT assay (A) and lipid accumulation (B) in 3T3-L1 cell line treated with Agastache rugosa extracts.

HE, hot-water extract of Agastache rugosa; EE, 70\% ethanol extracts of Agastache rugosa; ME, 70\% methanol extracts of Agastache rugosa. Means $\pm \mathrm{SD}(\mathrm{n}=3)$ in each column $\left({ }^{\mathrm{a}-\mathrm{h}}\right)$ followed by the same letter represents no significant difference $(\mathrm{p}<0.05)$.

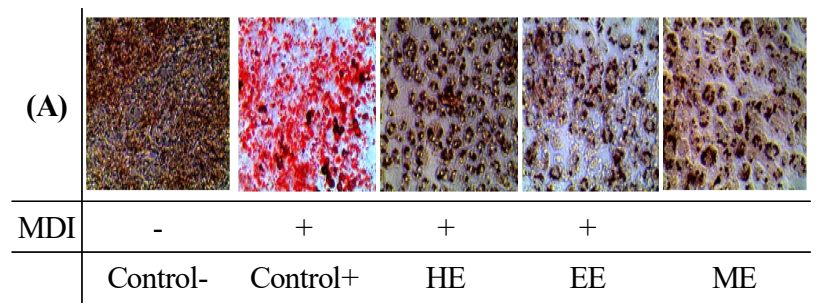

(B)

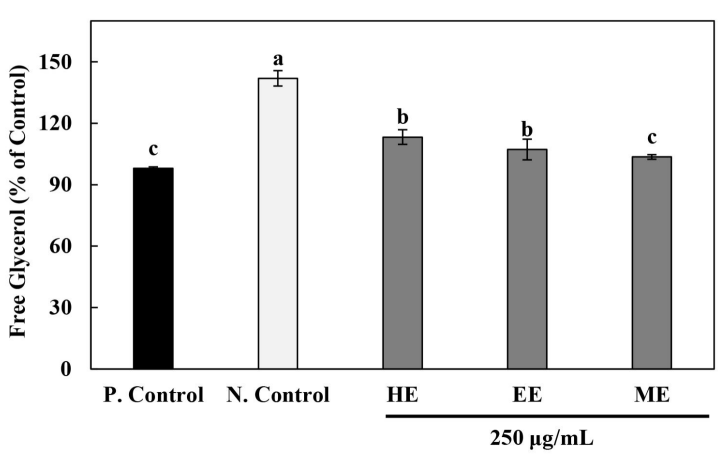

Fig 5. Lipid accumulation in differentiated adipocytes visualized by Oil-Red $O$ staining (A) and Free glycerol contents (B) in 3T3-L1 cell line treated with Agastache rugosa extracts.

HE, hot-water extract of Agastache rugosa; EE, 70\% ethanol extracts of Agastache rugosa; ME, 70\% methanol extracts of Agastache rugosa. MDI, methylisobutylxanthine, dexamethasone, insuline.

Means $\pm \operatorname{SD}(n=3)$ in each column $\left(^{a-c}\right)$ followed by the same letter represents no significant difference $(p<0.05)$.
지방 내 축적된 중성지방은 지방구에 존재하는 $\mathrm{TG}$ 가 분해 되면 유리지방산과 glycerol로 혈액 속으로 방출되어 간으로 이동하며, 3T3-L1 세포에서는 유리된 glycerol의 함량 측정 으로 지방구 내 중성지방의 분해 정도를 간접적으로 확인할 수 있다(Lee 등, 2014). 추출 용매에 따른 배초향 추출물의 free glycerol 함량은 Fig. 5에 나타냈다. 모든 시료 처리구에 서 분화유도 후, 시료처리하지 않은 Control 대비 낮은 함량을 나타냈으며, $70 \%$ 메탄올 추출물 $(250 \mu \mathrm{g} / \mathrm{mL})$ 에서 $103.63 \%$ 로 가장 낮은 함량을 보여주었다. Jeon 등(2014)은 어린 으름잎 추출물의 free glycerol 함량 측정 결과, 지방분화 유도한 Control 대비 낮은 함량을 나타냈다고 보고하였으며, 이는 지 방구 생성 감소, 지방세포의 지방구 내 중성지방 함량 감소와 더불어 배양액으로 유출되는 free glycerol 함량의 감소에 의 한 것으로 보고하였다. 따라서 배초향 추출물은 지방축적 억 제 효과가 있는 것으로 사료된다. Kim 등(2015)은 배초향의 지방합성 인자 조절 및 식이 섭취 감소를 통한 항비만 효능 측정을 위해 수컷 $\mathrm{C} 57 \mathrm{BL} / 6$ mice를 구입하여 실험을 진행하 였으며, 생리식염수를 투여한 대조군과 배초향 추출물 200 $\mathrm{mg} / \mathrm{kg}$ 을 $200 \mu \mathrm{L}$ 씩 4주 동안 경구 투여한 결과, 배초향 추출 물 투여군에서 고지방식이 섭취로 인하여 증가된 지방세포의 크기를 감소시켜 정상 수준으로 회복시켰다고 보고하였다. Rosmarinic acid는 꿀풀과의 식물에서 주로 높은 함유량을 나타내며, 배초향의 생리활성 물질을 나타내는 대표적인 성 분 중 하나로서 혈중에 흩어진 당분을 체외로 배출시켜 혈당 치의 상승을 억제하여 고혈압, 당뇨, 고지혈증 등을 예방하는 것으로 알려져 있다(Lee 등, 2009). 이러한 rosmarinic acid의 효능으로 인하여 배초향의 항비만 활성이 나타난 것으로 판 단되며, 항비만 기능성 식품 소재로서 배초향 추출물이 사용 되기 위해 향후 적절한 농도 선정을 위한 추가적인 연구가 필요하다고 사료된다.

\section{요 약}

본 연구에서는 배초향의 기능성 식품 소재로서의 활용 가 능성을 확인하기 위하여 추출 용매에 따른 추출물을 제조하 여 이화학적 품질 특성, 면역조절효과 및 항비만 활성을 조사 하였다. 증류수, $70 \%$ 에탄올 및 $70 \%$ 메탄올을 사용하여 추 출물을 제조하였으며, 추출 수율은 열수 추출물에서 $8.86 \%$ 로 가장 높이 측정되었으며, 총당 함량은 열수 추출물에서 33.98 $\mathrm{g} / 100 \mathrm{~g}$ 으로 가장 높게 나타내었다. 총단백 함량 측정 결과, 추출물별로 유의적인 차이를 나타내지 않았으며, 총폴리페놀 함량 측정 결과 $16.02 \mathrm{~g} / 100 \mathrm{~g}$ 으로 $70 \%$ 메탄올 추출물에서 가장 높게 나타났다. DPPH radical 소거활성은 $70 \%$ 메탄올 추출물 $(1,000 \mu \mathrm{g} / \mathrm{mL})$ 에서 $61.05 \%$ 로 가장 높게 나타났으며, 
$\mathrm{ABTS}$ radical 소거활성, FRAP 활성 및 $\mathrm{ORAC}$ value는 $70 \%$ 에탄올 추출물에서 가장 높은 활성을 나타내었다. 배초향 추 출물의 NO 생성 억제능 측정 결과, $70 \%$ 에탄올 추출물 1,000 $\mu \mathrm{g} / \mathrm{mL}$ 에서 $7.55 \mu \mathrm{M}$ 로 가장 높은 억제능을 나타내었으며, 가 장 높은 억제능을 나타낸 $70 \%$ 에탄올 추출물의 TNF- $\alpha$ 함량 은 54.06-70.57 pg/mL였으며, IL-6 함량은 25.41-32.68 $\mathrm{pg} / \mathrm{mL}$ 로 나타나 모두 농도 의존적으로 함량이 감소함을 확 인하였다. 또한, 3T3-L1 세포를 통해 지방세포 분화억제 효 과는 $70 \%$ 메탄올 추출물 $(500 \mu \mathrm{g} / \mathrm{mL})$ 에서 $29.48 \%$ 로 가장 높 은 억제능을 나타냈으며, free glycerol 함량은 $70 \%$ 메탄올 추출물 $(250 \mu \mathrm{g} / \mathrm{mL})$ 에서 $103.63 \%$ 로 가장 낮은 함량을 나타 내었다.

\section{Conflict of interests}

The authors declare no potential conflict of interest.

\section{ORCID}

Ji Wan Kim https://orcid.org/0000-0002-9680-8738

Joo-Heon Hong https://orcid.org/0000-0003-4360-3111

\section{References}

Anderson JW. Dietary fiber in nutrition management of diabetes. Dietary Fiber, 343-360 (1986)

Benzie IFF, Strain JJ. The ferric reducing ability of plasma (FRAP) as a measure of "antioxidant power": The FRAP assay. Anal Biochem, 239, 70-76 (1996)

Blois MS. Antioxidant determinations by the use of a stable free radical. Nature, 181, 1199-1200 (1958)

Bradford MM. A rapid and sensitive method for the quantitation of microgram quantities of protein utilizing the principle of protein-dye binding. Anal Biochem, 72, 248-254 (1976)

Castoldi A, Naffah de Souza C, Camara NOS, MoraesVieira PM. The macrophage switch in obesity development. Front Immunol, 6, 637 (2016)

Cha JY, Ahn HY, Eom KE, Park BK, Jun BS, Cho YS. Antioxidative activity of Aralia elata shoot and leaf extracts. J Life Sci, 5, 652-658 (2009)

Cheon YP, Mohammad LM, Park CH, Hong JH, Lee GD, Song JC, Kim KS. Bulnesia sarmienti aqueous extract inhibits inflammation in LPS-stimulated RAW 264.7 cells. J Life Sci, 19, 479-485 (2009)

Cho JY, Kim YS, Park YJ, Bae JH, Oh DM, Park SM, Heo BG. Physiological activity of Agastache rugosa extract. J Life Sci Nat Res, 1, 1-8 (2011)

Choi JH, Chung SK. Antioxidant and antimicrobial activities of polyphenols isolated from unripe apples (Malus pumila cv. Hongro). Korean J Food Preserv, 26, 690696 (2019)

Chua S, Leibel RL. Obesity genes: Molecular and metabolic mechansims. Diabetes Rev, 5, $2-7$ (1997)

Dong S, Jung SH, Moon JS, Rhee SK, Son JY. Antioxidant activities of clove by extraction solvent. J Korean Soc Food Sci Nutr, 33, 609-613 (2004)

Dong W, Azcona-Olivera JI, Brooks KH, Linz JE, Pestka JJ. Elevated gene expression and production of interleukins 2,4,5 nad 6 during exposure to vomitoxin (deoxynivalenol) and cycloheximide in the EL-4 thymoma. Toxicol Appl Pharmacol, 127, 282-290 (1994)

Dubois M, Gilles KA, Hamilton JK, Rebers PA, Smith F. Colorimetric method for determination of sugars and related substances. Anal Chem, 28, 350-356 (1956)

Ham HM, Woo KS, Park JY, Lee BW, Choi YH, Lee CW, Kim WH, Lee JS, Lee YY. Antioxidant and antiproliferative activities of oats under different solvent extraction conditions. J Korean Soc Food Sci Nutr, 45, 918-922 (2016)

Jeon YS, You YH, Jun WJ. Anti-obesity effects of extracts from young Akebia quinata D. leaves. J Korean Soc Food Sci Nutr, 43, 200-206 (2014)

Ji HH, Jeong HY, Jin SJ, Kwon HJ, Kim BW. Inhibition of adipocyte differentiation by methanol extracts of Oenanthe javanica seed in 3T3-L1 preadipocytes. J Life Sci, 12, 1688-1696 (2012)

Ji YJ, Lee EY, Lee JY, Lee YJ, Lee SE, Seo KH, Kim HD. Antioxidant and anti-diabetic effects of Agastache rugosa extract. J East Asian Soc Diet Life, 30, 297-305 (2020)

Kalupahana NS, Moustaid-Moussa N, Claycombe KJ. Immunity as a link between obesity and insulin resistance. Mol Aspects Med, 33, 26-34 (2012)

Kang ES, Ham SA, Hwang JS, Lee CK, Seo HG. Effects of Garcinia cambogia extract on the adipogenic differentiation and lipotoxicity. Korean J Food Sci An, 33, 411-416 (2013)

Kim DH, Bok YO, Lee HS, Woo WH, Mun YJ. Antioxidant 
activities of Plunus mume flower buds extract by various solvents. J Physiol Pathol Korean Med, 31, 188-193 (2017)

Kim DW, Yun HJ, Heo JY, Kim TH, Cho HJ, Park SD. Anti-oxidative and anti-inflammatory effect of Do-KiTang methanol extract in mouse macrophage cells. Kor J Herbology, 25, 103-112 (2010)

Kim HH, Kwon JH, Park KH, Kim MH, Oh MH, Choe KI, Park SH, Jin HY, Kim SS, Lee MW. Screening of antioxidative activities and antiinflammatory activities in local native plants. Kor J Pharmacogn, 43, 85-93 (2012)

Kim KC, Kim JS. Physiological activity of the extract from Dolwoe (Gynostemma pentaphyllum Makino) leaves tea by different ethanol concentrations. J Plant Biotechnol, 46, 37-44 (2019)

Kim NS, Shon MS, Kim GN, Hwang YI. Anti-obese and antioxidant activities of Spica prunellae extract in 3T3-L1 and HepG2 cells. Food Eng Prog, 18, 413-418 (2014)

Kim NY, Park DS, Lee HY. Effect of anti-skin wrinkle and antioxidant of Agastache rugosa Kentz through fermentation process of the lactic acid. Korean $\mathrm{J}$ Medicinal Crop Sci, 23, 37-42 (2015)

Kim SO, Kim MR, Hwag KA, Park NJ, Jeong JS. Inhibition of differentiation and anti-adipogenetic effect of the Salvia plebeia $\mathrm{R}$. Br. ethanol extract in murine adipocytes, 3T3-L1 cells. J Korean Soc Food Sci Nutr, 46, 401-408 (2017)

Kim YM, Kim MH, Yang WM. Effects of Agastache rugosa on obesity via inhibition of peroxisome proliferatoractivated receptor-gamma and reduction of food intake. J Korean Med Obes Res, 15, 104-110 (2015)

Kwak CS, Choi HI. In vitro antioxidant and antiinflammatory activities of ethanol extract and sequential fractions of flowers of Prunus persica in LPSstimulated RAW 264.7 macrophages. J Korean Soc Food Sci Nutr, 44, 1439-1449 (2015)

Lee HK, Byon SJ, Oh SR, Kim JI, Kim YH, Lee CO. Diterpenoids from the roots of Agastache rugosa and their cytotoxic acticities. Kor J Pharmacogn, 25, 379-327 (1994)

Lee HS, Lee HA, Hong CO, Yang SY, Hong SY, Park SY, Lee HJ, Lee KW. Quantification of caffeic acid and rosmarinic acid and antioxidant activities of hot-water extracts from leaves of Perilla frutescens. Korean $\mathrm{J}$ Food Sci Technol, 41, 302-306 (2009)

Lee JE, Lee JY, Choi JI, Kim CK, Kim SJ. Supression of nitric oxide and interleukin-6 production by methanol extract of Sophorae flos in macrophage cells. J Korean Acad Periodontol, 35, 9-19, (2005)

Lee MH, Nam DE, Kim OK, Heo SH, Lee JM. Lipolytic effect of supercritical extraction from pine cone (Pinus koraiensis) in mature 3T3-L1 adipocytes. J Korean Soc Food Sci Nutr, 43, 1342-1348 (2014)

Lee SG, Lee EJ, Park WD, Kim JB, Choi SW. Antioxidant and anti-inflammatory activities of extracts from Korean traditional medicinal prescriptions. Korean J Food Sci Technol, 43, 624-632 (2011)

Lee SO, Lee HJ, Yu MH, Im HG, Lee IS. Total polyphenol contents and antioxidant activities of methanol extracts from vegetables produced in Ullung island. Korean $\mathrm{J}$ Food Sci Technol, 37, 233-240 (2005)

Lee YB, Ham YM, Yoon SA, Oh DJ, Song SM, Hong IC, Lee ST, Hyun HB, Kim CS, Yoon WJ. Antioxidant and anti-inflammatory activities of crude extract and solvent fractions of Allium hookeri. J Korean Soc Food Sci Nutr, 46, 18-25 (2017)

Lim SR, Lee JA. Antioxidant activity and anti-inflammatory effects of ethanol extract from Allium schoenoprasum. J Converg Inf Technol, 10, 232-239 (2020)

$\mathrm{Oh} \mathrm{HK}$. Antioxidant and anti-inflammatory activities of extracts from Eugenia caryophyllata Thunb. J Korean Soc Food Cult, 31, 481-488 (2016)

Ou B, Hampsch-Woodill M, Prior RL. Development and validation of an improved oxygen radical absorbance capacity assay using fluorescein as the fluorescent probe. J Agric Food Chem, 49, 4619-4626 (2001)

Park CY, Yoo HJ. Inflammation and obesity. J Korean Soc Endocrinol, 19, 97-108 (2004)

Park KB, Jung DS, Jin Y, Kim JH, Geum JH, Lee JM. Establishment and validation of an analytical method for quality control of health functional foods derived from Agastache rugosa. Anal Sci Technol, 32, 96-104 (2019)

Park SE, Yeo SH, Kim S. The effect of Cudrania tricuspidata fruit vinegar on LPS-induced inflammation in 3T3-L1 adipocytes. Korean J Food Preserv, 27, 809-816 (2020)

Park SI, Kim TS, Park CG, Kang MH. Nutritional and sensory of green leafy vegetables cultivated from 
medicinal plant seed. J East Asian Soc Dietary Life, 22, 271-277 (2012)

Park YH, Choi JH, Whang K, Lee SO, Yang SA, Yu MH. Inhibitory effects of lyophilized dropwort vinegar powder on adipocyte differentiation and inflammation. J Life Sci, 24, 476-484 (2014)

Prior RL, Wu X, Schaich K. Standardized methods for the determination of antioxidant capacity and phenolics in foods and biological and dietary supplements. J Agric Food Chem, 53, 4290-4302 (2005)

Rao MNA. Nitric oxide scavenging by curcuminoids. J Pharm Pharmacol, 49, 105-107 (1997)

Re R, Pellegrini N, Proteggente A, Pannala A, Yang M, Rice-Evans C. Antioxidant activity applying an improved ABTS radical cation decolorization assay. Free Radical Biol Med, 26, 1231-1237 (1999)

Rose DP, Gracheck PJ, Vona-Davis L. The interactions of obesity, inflammation and insulin resistance in breast cancer. Cancers, 7, 2147-2168 (2015)

Singleton VL, Rossi JA. Colorimetry of total phenolics with phosphomolybdic-phosphotungstic acid reagents. Am J Enol Vitic, 16, 144-158 (1965)

Song HS, Lee GL. Conyza canadensis (L.) extract analysis of ingredients and anti-inflammatory anti-obesity activity. J Korea Soc Beauty Art, 18, 231-241 (2017)

Storck M, Schilling M, Burkhardt K, Prestel R, Abendroth D, Hammer C. Production of proinflammatory cytokines and adhesion molecules in ex-vivo xenogeneic kidney perfusion. Transpl Int, 7, S647-S649 (1994)
Van Meerloo J, Kaspers GJ, Cloos J. Cell sensitivity assays: The MTT assay. In: Cancer Cell Culture: Methods and Protocols, Humana Press, New York, NY, USA, p 237-245, 731 (2011)

Won BY, Shin KY, Ha HJ, Yun YS, Kim YR, Lee HG. Changes in nutritional composition of dropwort (Oenanthe javanica) ethanol extracts. J Korean Soc Food Sci Nutr, 44, 882-887 (2015)

Yeh WC, Bierer BE, McKnight SL. Rapamycin inhibits clonal expansion and adipogenic differentiation of 3T3-L1 cells. Proc Natl Acad Sci, 92, 11086-11090 (1995)

Yoon I, Wee JH, Moon JH, Ahn TH, Park KH. Isolation and identification of quercetin with antioxidative activity from the fruits of Rubus coreanum Muquel. Korean J Food Sci Technol, 35, 499-502 (2003)

Yoon SB, Han HS, Lee YJ. Effect of scutellariae radix extract on the proinflammatory mediators in Raw 264.7 cells induced by LPS. Kor J Herbology, 26, 75-81 (2011)

You SH, Jang MR, Kim GH. Antioxidant activity and neuroprotective effect of root bark of Morus alba L. extract against hydrogen peroxide-induced cytotoxicity in PC12 cells. J Korean Soc Food Sci Nutr, 47, 519-527 (2018)

Yun MS, Kim CH, Hwang JK. Agastache rugosa Kuntze attenuates UVB-induced photoaging in hairless mice through the regulation of MAPK/AP-1 and TGF- $\beta /$ smad pathways. J Microbiol Biotechnol, 29, 1349-1360 (2019) 